\title{
Some Benefits Of Reducing Inflation In South Africa
}

Rangan Gupta, University of Pretoria, South Africa

Josine Uwilingiye, PhD candidate, University of Pretoria, South Africa

\begin{abstract}
This paper evaluates the welfare gain from permanently reducing inflation from two percent to price stability and compares it the output cost associated with this transition. The paper emphasizes the distortions caused by the interaction of inflation and capital income taxation in calculating the gain from moving to a zero rate of inflation. Though the annual deadweight loss of a two percent inflation rate is 0.225 percent of GDP - a relatively small number when compared to the literature, since the real gain from shifting to price stability grows in perpetuity at the rate of growth of GDP, the present value is a substantial multiple of the annual welfare gain. Calculations reveal a present value gain of 15 percent of GDP. Since the corresponding one-off output cost of moving from two percent inflation to price stability is 0.034 percent of GDP, the gain outweighs the cost by an overwhelming margin.
\end{abstract}

Keywords: Inflation; Non-Indexed Tax System; Welfare Cost

\section{INTRODUCTION}

S outh Africa moved to an inflation targeting framework in February of 2000. Ever since, the sole objective of the South African Reserve Bank (SARB) has been to ensure that inflation lies within the target band of 3-6 percent. In this regard, the measurement of costs and benefits of inflation is of paramount importance in determining the legitimacy of the current target band and if there is a need to rethink the band in terms of the welfare cost of inflation at least. Among the costs, those that are caused by the interaction of inflation with tax rules need to be emphasized. Due to the non-indexation of the South African tax system, inflation exacerbates the inefficiencies generated by taxation. The quantitative significance of these efficiencies is likely to be particularly strong in case of taxation of capital - a mobile factor of production. Building on the methodological foundation of Feldstein's (1997, 1999) approaches, this paper examines the welfare implications of the interaction between capital income taxation and inflation. We consider the per-year welfare effects of going from 2 percent $^{1}$ inflation to price stability and compare them with the output costs of disinflation.

Based on the recent estimate of interest elasticity of money for South Africa, obtained by Gupta and Uwilingiye (2009b), a two percent inflation rate would translate into a welfare loss of 0.098 percent of Gross Domestic Product (GDP) using Bailey's (1956) consumer surplus approach. ${ }^{2}$ However, it must be realized that welfare cost calculations obtained by integrating under the money demand curve as the interest rate rises from zero to a positive value to obtain the lost consumer surplus and then deducting the associated seigniorage revenue to deduce the deadweight loss, is merely one-dimensional. This is because the consumer surplus approach fails to account for the fact that inflation, operating in conjunction with the tax system, has further distortionary effects on the intertemporal consumption choice (i.e., saving for old age), housing and the real cost of servicing government debt. Thus, the welfare costs obtained using the money demand approach is likely to provide the lower limit of such estimates, and hence, a more general approach, like the one adopted here, is desired to obtain the "true" size of the

\footnotetext{
${ }^{1}$ Note the calculations are symmetric and, approximately, linear. Therefore, it is not difficult to translate the estimates, obtained under an inflation rate of 2 percent, for the width of the target band. The decision to use a 2 percent rate of inflation is dictated by the approach in the original contributions of Feldstein $(1997,1999)$, and the literature that followed thereof.

${ }^{2}$ See Gupta and Uwilingiye (2008, 2009a) for further details.
} 
welfare loss caused by inflation. It must, however, be stressed that recent evidence ${ }^{3}$ on the sacrifice ratio of South Africa tends to suggest that disinflation can be achieved at virtually no loss to employment and output. Given this and Feldstein's $(1997,1999)$ arguments that costs of disinflation are temporary while the benefits are permanent; i.e., one needs to compare the discounted stream of benefits with one-off output costs, even a small-sized estimated benefit could imply relatively large overall gain from a permanent disinflation of two percent.To the best of our knowledge, this is the first attempt to measure the welfare cost of inflation for the South African economy using Feldstein's $(1997,1999)$ approaches that account for interactions between the tax system and inflation. ${ }^{4}$

\section{THEORETICAL BACKGROUND}

At the moment, most tax systems around the world are not completely indexed to ensure that the price-level changes leave real tax rates and real tax revenue unchanged. Inflation-induced distortions generated by the interaction of inflation and the non-indexed tax system have the potential to be much larger than the revenue-related effects on which most of the seigniorage and optimal inflation literature has focused (Walsh, 2003).

One important distortion arises when nominal income, and not real interest income, is taxed. It must be realized that it is after tax real rates of return that is relevant for individual agents in making saving and portfolio decisions, and if nominal income is subject to a tax rate of $\tau$, the real after -tax return will be

$$
\begin{aligned}
& r_{a}=(1-\tau) i-\pi \\
& =(1-\tau) r-\tau \pi,
\end{aligned}
$$

where $i=r+\pi$ is the nominal return and $r$ is the before-tax real return. Thus, for a given pre-tax real return $r$, the after-tax real return is decreasing in the rate of inflation. Practically speaking, let us consider a two-period overlapping generations model where an individual works and earns an income when young and also decides on how much to consume now and save for their old age. Suppose that savings are invested at the rate of $r$. Therefore, consumption in old age is related to savings by the following equation:

$$
c=s(1+r)^{T}
$$

where $T$ is the length of the period between saving while young and dissaving in the old age. Then price of retirement consumption can be defined as

$$
p=\frac{1}{(1+r)^{T}}
$$

Clearly, the relative price of old-age consumption $P$ is affected by both tax system and inflation, since they distort the choice between current consumption and future consumption. Graphically, the scenario is depicted in Figure 1.

Figure 1 depicts the individual's compensated demand for retirement consumption, labeled as Quantity, as a function of the price of retirement consumption $p$, denoted as Price, at the time of the decision to save. The different points on the graph represent different scenarios. With combination $c_{0}, p_{0}$ representing consumption decision without tax and inflation, the consumer surplus is $\mathrm{A}+\mathrm{B}+\mathrm{C} \ldots .+\mathrm{F}$. Introducing income taxes in an environment of price stability (no inflation) moves the equilibrium point from $c_{0}, p_{0}$ to $c_{1}, p_{1}$ which leads to a lesser

\footnotetext{
${ }^{3}$ See for example Akinboade et al. (2004), Woglom (2005), Gonçalves and Carvalho (2008), and Tunali (2008).

${ }^{4}$ For applications of Feldstein's $(1997,1999)$ approaches on other countries, refer to Bonato (1998) for New Zealand, Bakhshi et al., (1999) for the United Kingdom, Dolado et al., (1999) for Spain, Tödter and Ziebarth (1999) for Germany, O’Reilly and Levac (2000) for Canada and Blaszkiewicz et al., (2003) for Poland and Ukraine.
} 
retirement consumption at a higher price. Consumer surplus is now reduced to the area $\mathrm{C}+\mathrm{E}+\mathrm{F}$ and the tax revenue corresponding to that area is $\mathrm{B}+\mathrm{D}$. Triangle $\mathrm{A}$, thus, represents the deadweight loss, which, in turn, is the reduction of consumer surplus not compensated by higher tax revenues. When we introduce both taxes and inflation at the equilibrium point from $c_{1}, p_{1}$ to $c_{2}, p_{2}$, again there is a reduction in consumption at a high price. The consumer surplus remaining is $\mathrm{F}$ and tax revenue is the rectangle $\mathrm{D}+\mathrm{E}$. The deadweight loss increases from triangle $\mathrm{A}$ to triangle $\mathrm{A}+\mathrm{B}+\mathrm{C}$.

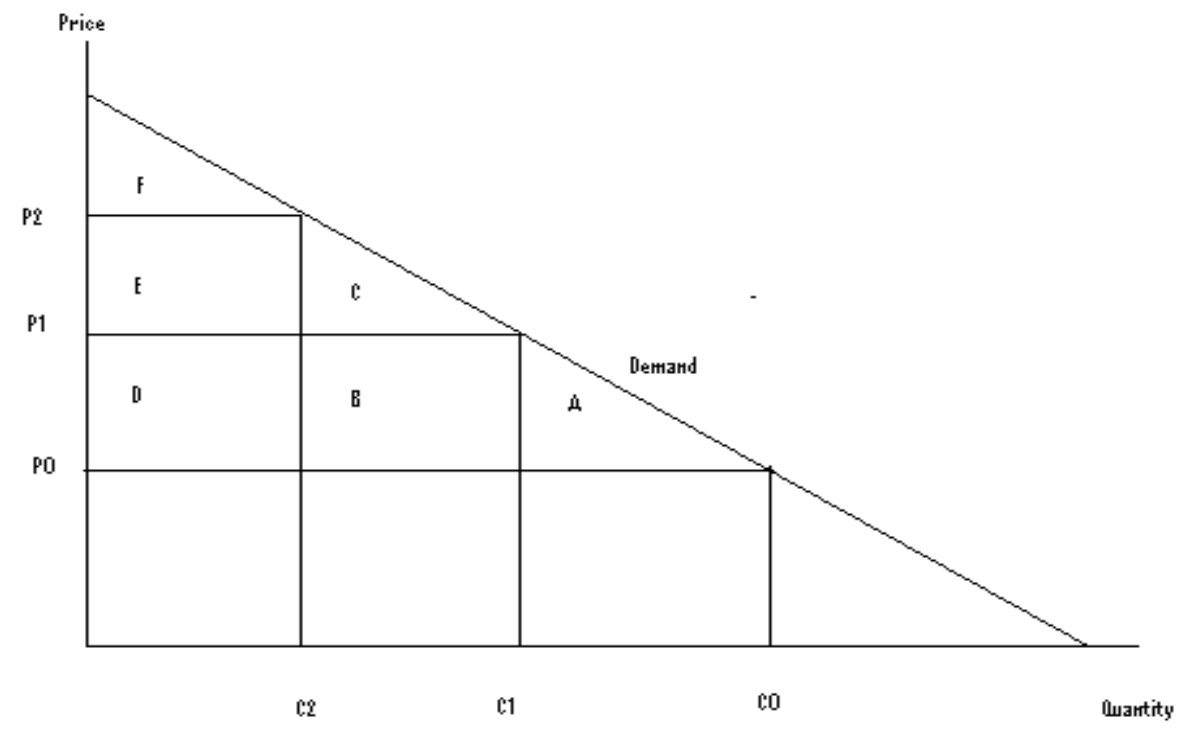

Figure 1: Demand for Retirement Consumption

Thus, moving from equilibrium inflation to price stability increases consumer surplus by the area $\mathrm{C}+\mathrm{E}$, the tax revenues change to area B-E (which can be negative or positive), and the welfare gain is $\mathrm{B}+\mathrm{C}$, which is a trapezoid as shown above. Unlike the traditional welfare analysis where welfare changes were obtained using "Haberger triangles" and therefore were of the second order; i.e., small in the presence of distortionary taxes, the initial situation is not optimal and welfare changes are of the first order, as indicated by a trapezoid rather than the triangle.

\section{Inflation and the Inter-Temporal Allocation of Consumption}

\section{Distortions to Saving Behavior}

The household has two main decisions to be make on their expenditure; namely, how much to consume and how much to invest in each period. Feldstein (1997) derives the welfare gain from reducing inflation in a two period consumption model. Individuals are given an initial endowment and then they decide on the portions of their income to consume and save in the first period in order to consume when they are retired in the second period. The agent's first period savings earns a real rate of return, and in period one, the price of retirement consumption $(p)$ is thought to be inversely related to this rate of return; i.e., the higher the rate on saving, the cheaper the effective price of retirement consumption. The rate of return on saving depends on both inflation and the tax system. According to Feldstein et al. (1978), inflation is a source of irregular change on the effective tax rate of capital income, which leads to changes in real net of post-tax return. Taxes drive a wedge between the pre-tax rate of return, which is assumed to be invariant to inflation, and the post tax return that households earn. Higher inflation raises the tax wedge and reduces the effective real post-tax return to saving and increases the price of retirement consumption. Given this, the welfare gains associated with reduction in inflation with the current tax system can be obtained from the following expression: 


$$
G_{1}=B+C=\left[\left(\frac{p_{1}-p_{0}}{p_{2}}\right)+0.5\left(\frac{p_{2}-p_{1}}{p_{2}}\right)\right]\left(\frac{\left(p_{2}-p_{1}\right)}{p_{2}}\right) S_{2}\left(1-\eta_{s_{p}}-\sigma\right)
$$

where $p_{0}$ is the price of retirement consumption at zero inflation with no distortionary taxes, $p_{1}$ is the retirement price evaluated under the current tax regime with price stability (zero inflation), and $p_{2}$ is the price evaluated under the current tax regime with 2 percent inflation ${ }^{5} . s_{2}$ represents the initial gross saving of individual when young; $\eta_{s_{p}}$ is the uncompensated elasticity of saving with respect to the price of retirement consumption, and $\sigma$ is the propensity to save out of exogenous income.

Note that to calculate $p_{0}$, we need the pre-tax real rate of return on savings. For this purpose, we use the rate of return on equity which on average was equal to 7.06 percent $^{6}$ for the period 1990-2007. Assuming that at this rate of return, both inflation and taxes are non-existent and the time interval between saving and consumption is 30 years, $p_{0}=(1+0.0706)^{(-30)}=0.1292$. In order to calculate the real return to savings in a world of taxes and inflation, we need to adjust the above real rate of return on savings for both corporate and personal sector taxes. The average rate of corporate income tax between 1990 and 2007 was 25.68 percent $^{7}$ which, in turn, leaves a net real return $r$ to 5.25 percent before personal tax deductions. The net of tax rate of return depends not only on the tax at the corporate level, but also on the taxes that individuals pay on interest income, dividends and capital gains. The effective marginal tax rate depends on the form of income and on the tax status of the individual. Feldstein (1997) summarizes these effects by assuming a uniform individual marginal tax rate across all sources of income. Given this, the individual marginal tax rate in South Africa, across all sources of income, averaged 25 percent $^{8}$ over the $^{2}$ period 1990-2007. This reduces the net return further, to 3.94 percent. The price of retirement consumption that corresponds to this net return of 3.94 percent is therefore $p_{2}=(1.0394)^{(-30)}=0.3137$ where the subscript 2 on the price indicates the price of retirement at an inflation rate of 2 percent.

Reducing the equilibrium inflation rate from two percent to zero lowers the effective tax rate at both corporate and individual levels. At the corporate level, this has two opposing effects: 1) the changes in the equilibrium inflation rate alter the effective tax rate by changing the value of depreciation allowances and 2) it changes the value of the deduction of interest payments. Because the depreciation schedule that is allowed for calculating taxable profits is defined on the basis of historical nominal terms, a higher rate of inflation reduces the present value of depreciation and thereby increases the effective tax rate. This relation was approximated by Feldstein (1997) using a rule of thumb of 0.57 percent increase in taxable profit for each percentage point of inflation. Due to lack of this estimate in South Africa, we use the same value as Feldstein (1997). With marginal corporate income tax rate at 30 percent $^{9}$, a 2 percent reduction in inflation raises the net of tax return and hence, decreases the effective tax rate by $0.30(0.57)(0.02)=0.0034$ or 0.34 percentage points. The interaction of the interest deduction and inflation moves the after-tax yield in the opposite direction. If each percentage point of inflation raises the nominal corporate borrowing rate by one percentage point ${ }^{10}$, the real pre-tax cost of borrowing is unchanged, but companies get an addition deduction in calculating their taxable income. With debt to capital ratio of 59 percent ${ }^{11}$ and a corporate tax rate of 30 percent, a 2 percent decline in inflation raises the effective tax rate by

\footnotetext{
${ }^{5}$ Even though the inflation over the period of 1990-2007 was 7.3 percent on average, we decided to use a figure of 2 percent to make our analysis comparable with the literature that uses Feldstein's $(1997,1999)$ approaches. Note also, we consider the period of 1990-2007 for our calculations, due to data availability on all the relevant variables over this time period.

${ }^{6}$ The return on equity is calculated using the percentage change in the All Share Index (ALSI). Source: International Financial Statistics.

${ }^{7}$ Source: McGregory BFA.

${ }^{8}$ The value corresponds to the average of marginal individual tax rate and capital gains tax for individuals (Source: Tax Pocket Guide 2006/7).

${ }^{9}$ Source: The value corresponds to the average marginal corporate tax rate (Source: World Bank, World development Indicators).

${ }^{10}$ See footnote 24 in Feldstein (1997) for further details.

${ }^{11}$ Source: McGregory BFA. The value of debt to capital ratio is obtained by dividing total liabilities with total assets using balance sheets of all companies between 1990-2007.
} 
$0.30(0.59)(0.02)=0.0035$ or 0.35 percentage points. The difference of the two effects at corporate level is almost insignificant.

Beside the impact of inflation at the corporate level, the lower inflation rate affects the taxes at the individual level as well. As individual income taxes are levied on nominal interest payments and nominal capital gains, a reduction in the rate of inflation further reduces the effective tax rate and raises the real after-tax of return. The part of this relation that is associated with the taxation of nominal interest at the level of the individual can be approximated in a way that mirrors the effect at the corporate level. If the nominal interest rate increases by one percentage point for every percentage point of inflation, the individual investors' real pretax return on debt is unchanged, but the after tax return falls and is given by the product of the statutory marginal tax rate and the change in inflation. Assuming the same 59 percent debt share at the individual level, as assumed for the corporate capital stock, and 25 percent average individual marginal tax rate, a 2 percent decline in inflation lowers the effective tax rate by $0.25(0.59)(0.02)=0.003$ or 0.3 percentage points.

Next, we consider the effect of inflation on capital gains, excluding dividend, as the individual dividend return on capital ownership is unaffected by inflation except at the corporate level. A higher rate of inflation increases the taxation of capital gains. Even though the effective tax rate on capital gains is taxed at the same rate as other investment income, the effective tax rate is lower because the tax is only levied on realization of the gains. Given an effective tax rate of 10 percent ${ }^{12}$ on nominal capital gains in South Africa, in equilibrium, each percentage point increase in the price level raises the nominal value of the capital stock by one percentage point. Since the nominal value of the liabilities remains unchanged, the nominal value of the equity rises by $1 /(1-b)$ percentage point, where $b$ is the debt-to-capital ratio. With $b=0.59$ and an effective tax on nominal capital gain of 10 percent; i.e., $\theta_{g}=0.1$, a 2 percent decline in the rate of inflation raises the real after-tax rate of return on equity by $\theta_{g}[1 /(1-b)] d \pi=0.0049$ or 0.49 percentage points. However, since equity is assumed to represent 35 percent of the individual's portfolio ${ }^{13}$, the lower effective capital gains tax raises the overall rate of return by only 35 percent of this 0.49 percentage points or 0.17 percentage points. Combining the debt and capital effects implies that reducing the inflation rate by 2 percentage points reduces the effective tax rate at the individual investor level by the equivalent of 0.47 percentage points, with the real net return to the individual saver at 4.41 percent. This implies that price of retirement consumption is $p_{1}=0.2740$. Substituting these values for the price of retirement consumption into equation (4) yields:

$$
G_{1}=0.066 S_{2}\left(1-\eta_{s p}-\sigma\right)
$$

\section{The Saving Rate and the Saving Behavior}

The value of $S_{2}$ in equation 5 represents the savings during pre-retirement years at the existing inflation. To evaluate (5), we need an estimate of the savings of the young at an inflation rate of 2 percent $\left(S_{2}\right)$. Feldstein (1997) derives an estimate from the steady-state relationship between savers and dis-savers implied by the two-period model. He shows that the saving of the young is $(1+\eta+g)^{T}$ times the savings of the older generation, where $n$ is the rate of population growth and $g$ is the growth in per capita wages. Thus net personal savings $\left(S_{N}\right)$ is related to $S_{2}$ according to:

$S_{N}=S_{2}-(1+n+g)^{-T} S_{2}$

Real average wage growth in South Africa over the period 1990-2007 was 3.73 percent, while population growth was 1.71 percent. On the other hand, the average private saving rate over the same period was 5.4 percent of

\footnotetext{
${ }^{12}$ Source: Tax Pocket Guide 2006/7.

${ }^{13}$ Source: Financial Services Board.
} 
GDP. Based on these numbers, we have: $n+g=0.0218$ and with $T=30$, it implies $S_{2}=2.1 S_{N}$. Further, using private savings to be 5.4 percent of GDP results in $S_{2}=0.11 \mathrm{GDP}$. Further, the average share of wage in GDP between 1990 and 2007 was equal to 48 percent. Then, the propensity to save out of exogenous income is: $\sigma=S_{2}\left(\alpha^{*} G D P\right)$ where $\alpha$ is the share of wage in GDP. With $\alpha=0.48, \sigma=0.23$.

The final term to be evaluated in order to calculate the welfare gain described in equation 5 is the elasticity of savings with respect to real interest rate, since the uncompensated elasticity of savings, with respect to the price of retirement consumption, is related to elasticity with respect to the real rate of return as: $\eta_{s p}=\frac{\left.-(1+r) \eta_{s r}\right)}{r T}$. Following Dolado et al. (1998) and Balshki et al. (1998), we assume that $\eta_{s_{r}}=0.2 \cdot{ }^{14}$ As in Feldstein (1997), we also assume a value of $\eta_{s_{r}}=0$ to assess the sensitivity of this estimate to the value of $\eta_{s_{r}}$.

Given this, the annual gain from reduced distortion of consumption is $G_{1}=0.0069$ GDP or 0.69 percent of GDP when $\eta_{s_{r}}=0.2$, and for $\eta_{s_{r}}=0$, we have $G_{1}=0.0056 \mathrm{GDP}$ or 0.56 percent of GDP. These calculations suggest that the traditional welfare effect on the timing of consumption of a reduction in inflation rate by 2 percent is bound between 0.56 percentage points of GDP to 0.69 percentage point of GDP.

\section{Indirect Revenue Effects}

Next we consider the effect on government revenue of the above experiment. The working assumption here, as in Feldstein (1997), is that any reduction of government revenue due to a move from two percent inflation to price stability cannot be made good by a rise in lump-sum taxes. Instead, distortionary taxes are required to fill in the financial gap, with obvious corresponding welfare implications.

Assume that we start in a situation where the price of retirement income is $p_{2}$ and consumption level is $c_{2}$ (see Figure 1) with inflation at two percent and the current tax system in place. Now consider lowering the inflation rate to zero. There are two offsetting effects on revenue. On one hand, lower inflation raises the real return to saving, thus lowers the price of retirement to $p_{1}$. This results in a loss of revenue equal to $\left(p_{2}-p_{1}\right) c_{2}$. On the other hand, the lower price of retirement consumption stimulates higher consumption by $\left(c_{1}-c_{2}\right)$, which in turn, generates revenue by the amount of $\left(p_{1}-p_{0}\right) \times\left(c_{1}-c_{2}\right)$.

The change in revenue can thus be captured by:

$$
d \mathrm{REV}=S_{2}\left\{\left[\frac{p 1-p 0}{p^{2}}\right]\left[\frac{p 2-p 1}{p^{2}}\right]\left(1-\eta_{s p}-\sigma\right)-\left[\frac{p 2-p 1}{p^{2}}\right]\right\}
$$

This expression can, in principle, be either positive or negative, but in our case, it substitutes the earlier estimates for values $p_{0}, p_{1}, p_{2}$. We get net revenue loss of $d R E=-0.0079$ GDP or -0.79 percent of GDP for $\eta_{s_{r}}=0.2$ and $-0.009 \mathrm{GDP}$ or -0.9 percent of GDP for $\eta_{s_{r}}=0$. Assuming that $\lambda$ represents the dead weight loss when each rand of revenue that needs to be raised from other taxes due to loss in revenue, the net loss in revenue of shifting from two percent inflation to price stability is 0.36 percent and 0.32 percent of GDP under $\eta_{s r}=0$ and 0.2 , respectively. Note, following Feldstein (1997), $\lambda$ is set at 0.4. Overall, net welfare gain $\left(N G_{1}\right)$ from reducing inflation by 2 percent is then given by: $N G_{1}=G_{1}+\lambda d \operatorname{Re} v$. For $\lambda=0.4$, the net welfare gains are, respectively,

\footnotetext{
${ }^{14}$ The decision to use a value of 0.20 for $\eta_{s_{r}}$, which is, in general, the lower bond of this estimate available in the literature, is in line with the observation of low interest sensitivity of savings in South Africa.
} 
equal to 0.37 with $\eta_{s r}=0.2$ and 0.20 with $\eta_{s r}=0$. For $\lambda=1.5$, the welfare gains are forfeited for both $\eta_{s r}=0$ and $\eta_{s r}=0.2$.

\section{The Gain from Reducing Distortion in Housing Demand}

In some countries, owner-occupied housing is generally given special treatment on individual income taxation in order to encourage investment in housing and therefore stimulate economic growth. The benefit of owner-occupied housing is that the mortgage interest payments and property tax rates are tax deductible. This is not the case for South Africa, since such deductions are not applicable. According to (Bonato, 1998), when mortgage interest payment is not tax deductible, inflation only indirectly affects demand for housing. This leads to reduction in the return on alternative assets. The state of price stability reduces this distortion as well as the loss of tax revenue, by moving capital from housing to the business sector. Given this, welfare effect of inflation on housing demand can be graphically represented in Figure 2:

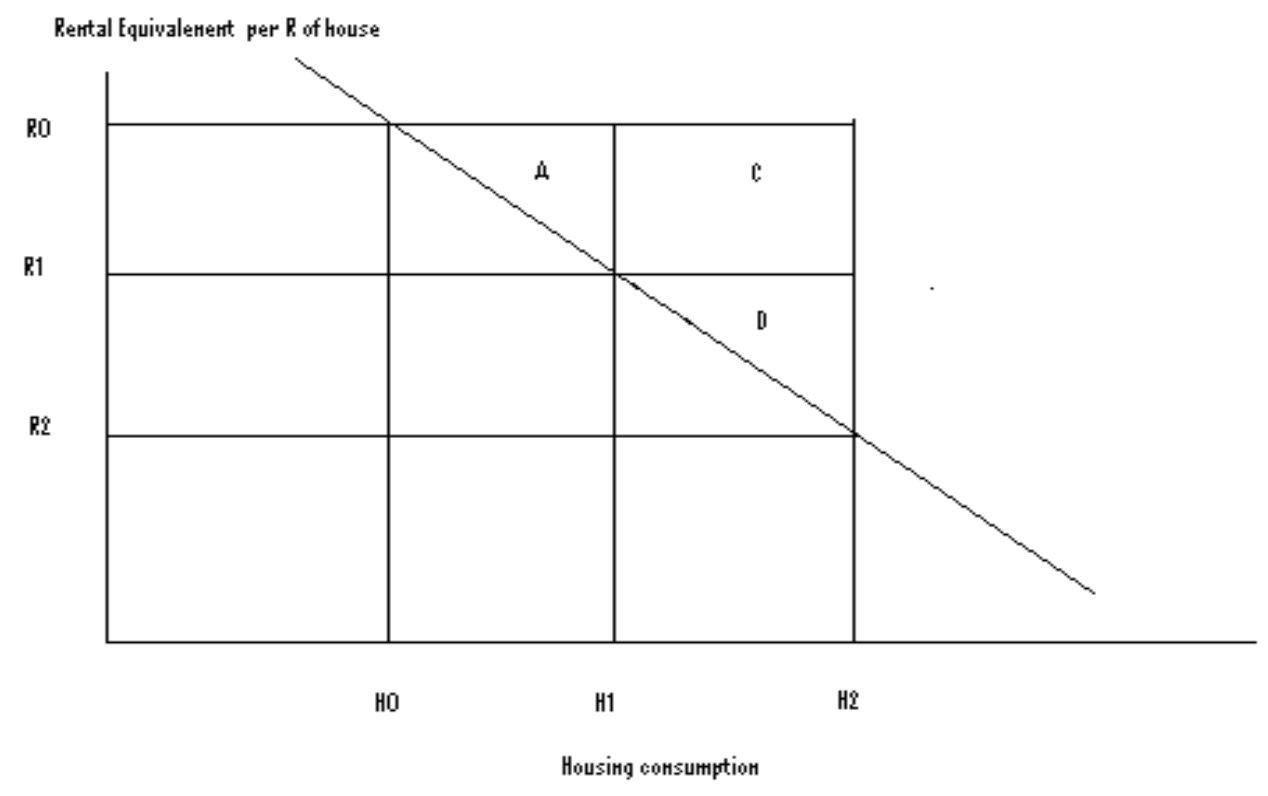

Figure 2. Distortion in Housing Demand

Figure 2 shows the compensated demand for housing services. The horizontal line at $R_{0}$ represents the undistorted cost of housing - the 'true' supply curve. The dead weight loss due to taxation is represented by triangle A, while the dead weight loss due to inflation is represented by the area of the trapezoid C+D. The reduction in the dead weight loss, that results from reducing the distortion to housing demand when the inflation declines from two percent to zero, is:

$G_{2}=\left[\left(R_{0}-R_{1}\right)+0.5\left(R_{1}-R_{2}\right)\right]\left(H_{2}-H_{1}\right)$

where $\left(H_{2}-H_{1}\right)=(d H / d R)\left(R_{2}-R_{1}\right)$

$=(d H / d R)\left(R_{2} / H_{2}\right)\left(H_{2} / R_{2}\right)\left(R_{2}-R_{1}\right)$ 
$=\varepsilon_{H R} H_{2} \frac{\left(R_{2}-R_{1}\right)}{R_{2}}$

Then,

$G_{2}=\varepsilon_{H R} R_{2} H_{2}\left\{\left[\frac{\left(R_{0}-R_{1}\right)}{R_{2}} \frac{\left(R_{1}-R_{2}\right)}{R_{2}}\right]+0.5\left[\frac{\left(R_{1}-R_{2}\right)}{R_{2}}\right]^{2}\right\}$

where $\varepsilon_{H R}$ is the compensated elasticity of housing demand with respect to the rental rate.

$\mathrm{H}_{2}$ is the demand for owner-occupied housing and $\mathrm{R}$ represents the rental cost of housing per rand of housing capital. In many countries, effective subsidies to housing demand, arising from the combination of inflation and tax system, reduces the implied rental cost of housing and leads to overconsumption of housing $\left(H_{2}\right)$, compared to situations of no taxes and no inflation $\left(H_{0}\right)$.

In the absence of tax and inflation, the implicit rental cost is equal to

$\mathrm{R}_{0}=r_{0}+m+\delta$

where $r_{0}$ is the return on real rate of return on equity, $m$ is the cost of maintenance per rand of housing capital, and $\delta$ is the rate of depreciation. With $r_{0}=0.0706, m=0.074{ }^{15}$ and $\delta=0.05{ }^{16}$ implies $\mathrm{R}_{0}=0.1946$.

With the current tax regime and inflation, the revised implicit rental cost is

$\mathrm{R}_{2}=\mu\left(r_{m}+\pi\right)+(1-\mu)\left(r_{n}+\pi\right)+\tau_{p}+m+\delta-\pi$

where $\mu$ is the loan-to-value ratio, $r_{m}$ is the real mortgage interest rate, $r_{n}$ is the rate of return on equity with taxes and two percent inflation rate, and $\tau_{p}$ is the property tax rate. With $\mu$ equal to $0.7^{17}, r_{m}+\pi$ equal to $0.097^{18}$ and $\tau_{p}$ equal to $0.002^{19}, R_{2}=0.1913$. The combination of tax and two percent inflation reduces the rental cost from 19.46 cents per rand of housing capital to 19.13 cents per rand of housing capital.

Next we look at the effect of a decrease in the rate of inflation on this implicit rental cost of owneroccupied housing:

$d \mathrm{R}_{2}=\mu^{*} d r_{m} / d \pi+(1-\mu) d\left(r_{n}+\pi\right) / d \pi-1$.

With $r_{1}=0.0441$ at $\pi=0$ and $r_{n}=0.0394$ at $\pi=0.02, d r_{n} / d \pi=-0.235$ and $d\left(r_{n}+\pi\right) / d \pi=0.765$. Therefore,

$d \mathrm{R}_{2} / d \pi=\mu+0.765(1-\mu)-1$.

$=-0.0705$.

${ }_{16}^{15}$ Source: Statistics South Africa.

${ }^{16}$ Source: National Department of Housing, South Africa.

${ }^{17}$ Source: Standard Bank of South Africa Limited.

${ }^{18}$ Source: SARB.

${ }^{19}$ Source: SARB. 
Since $R_{2}=0.1913$ at two percent inflation, this implies $R_{1}=0.1927$ at zero inflation.

We now go on and calculate $G_{2}$. Due to the lack of data on housing stock and rental rates in South Africa, we use an elasticity of 0.3 as in Bonato (1998). ${ }^{20}$ With $H_{2}$ equal to 2.08 , which is gross fixed capital formation for residential building as a percentage of $\mathrm{GDP}^{21}$, the welfare gain is equal to 0.001 percent of GDP.

\section{Indirect Revenue Effects}

In the case of owner-occupied housing, zero inflation would result in an increase in tax revenues. Shifting capital from owner-occupied housing to business capital will lead to additional revenue equal to

$d \operatorname{Re} v_{1}=\varepsilon_{H R} \frac{R_{1}-R_{2}}{R_{2}} H_{2}\left(r_{0}-r_{1}\right)$

$=0.012$ percent of GDP

Secondly, this increase in tax revenue is partly offset by a loss in the revenue from property taxes due to reduction of the housing stock. This loss can be estimated as

$d \operatorname{Re} v_{2}=\varepsilon_{H R} \frac{R_{1}-R_{2}}{R_{2}} H_{2} \tau_{p}$

$=0.0009$

Assuming a constant debt to GDP ratio, the increases in the real value of interest payments is equal to the product of the change in inflation times the marginal tax rate on interest payment, $\theta_{i}$ (which we assume to be equal to average marginal individual tax rate) times the ratio of debt, $B$, to GDP, as shown in Feldstein (1997).

\section{Seigniorage and Distortion of Money Demand}

Money Demand

An increase in inflation raises the cost of holding non-interest bearing money balances and therefore reduces the demand for such balances below the optimal level. It is this resulting dead weight loss of inflation that has been the primary focus of literature on the welfare effects of inflation since Bailey's (1956) pioneering paper.

Assuming that the initial situation is characterized with inflation $\pi_{2}$ and a positive nominal interest rate $i_{n 2}=r_{n 2}+\pi_{2}$, reducing inflation entails a welfare gain. Graphically, this can be depicted as shown in Figure 3:

\footnotetext{
${ }^{20}$ Given the inelastic rental market in South Africa, we believe that the choice of this value is a reasonable one.

${ }^{21}$ Source: SARB.
} 


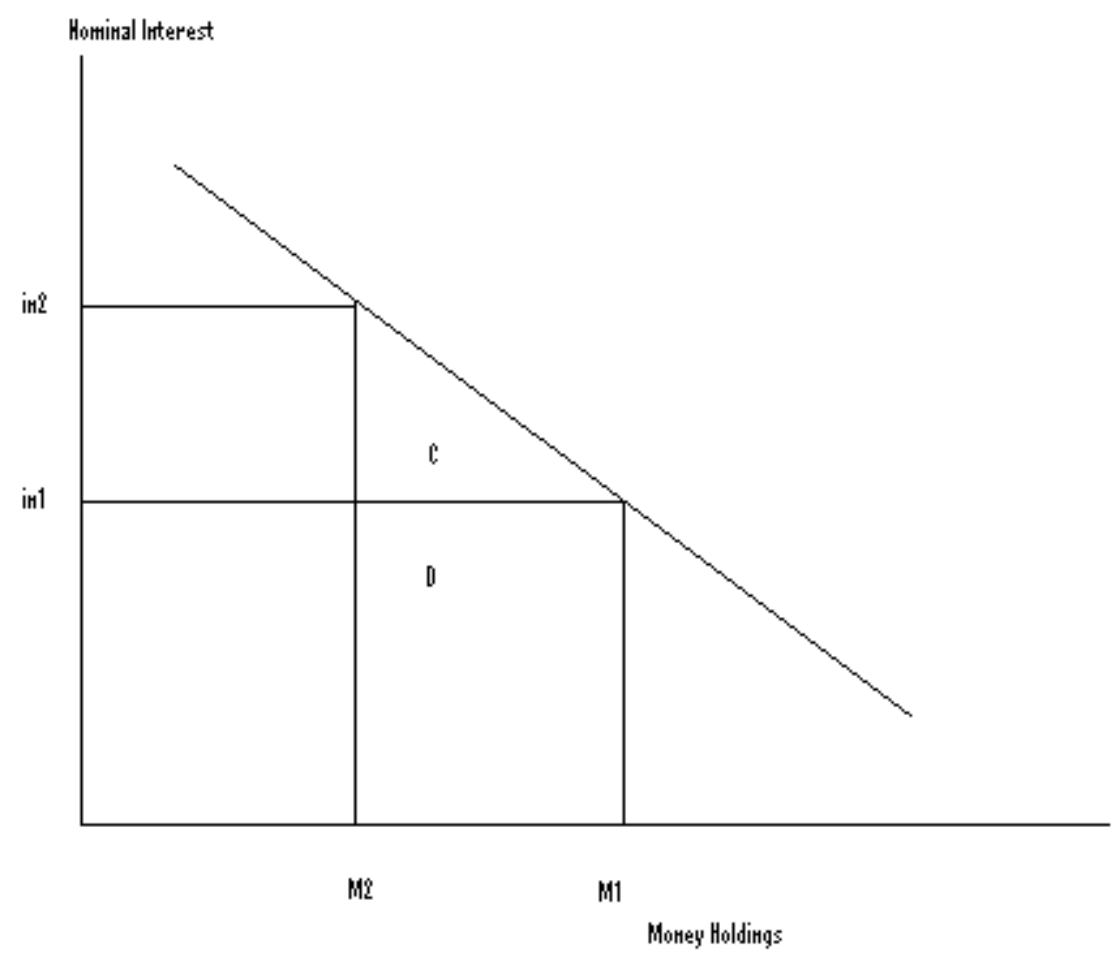

Figure 3: Money Market Distortion

As shown in the Figure 3 above, which plots the demand for money as a function of nominal interest rate, a reduction in inflation (from $\pi_{2}$ to $\pi_{1}$ ) leads to an increase in money demand (from $M_{1}$ to $M_{2}$ ) and to a welfare gain presented by the area $\mathrm{C}$ plus the area $\mathrm{D}$ between the money demand curve and zero opportunity cost line. To compute the welfare gain, it is necessary to estimate the change in nominal interest rates caused by the reduction in inflation and induced increase in money demand $\left(M_{1}-M_{2}\right)$. Recall that with a true initial inflation $\pi_{2}$ of 2 percent, the real net of tax return in South Africa is 3.94 percent, which leads to a nominal interest rate $i_{n 2}$ of 5.94 percent.

With $d r / d \pi=-0.235$

$$
\begin{aligned}
& G_{3}=i_{n l}\left(M_{1}-M_{2}\right)+\frac{1}{2}\left(i_{n 2}-i_{n l}\right)\left(M_{1}-M_{2}\right) \\
& =0.0441\left(M_{1}-M_{2}\right)+0.5(0.0594-0.0441)\left(M_{1}-M_{2}\right) \\
& =0.05175\left(M_{1}-M_{2}\right) \\
& =-0.05175 \varepsilon_{M} M \frac{1}{r_{n}+\pi} 0.0153 \\
& =0.00079 \varepsilon_{M} \frac{M}{G D P}\left(r_{n}+\pi\right)^{-1} G D P
\end{aligned}
$$


Since the demand deposit component of M1 is now generally interest-bearing, non-interest-bearing money in South Africa is represented by M1A. Between 1990 and 2007, the ratio of currency in circulation to GDP was 15.3 percent, thus $\mathrm{M}=0.153 \mathrm{GDP}$. Using Meltzer's (1963) log-log money demand specification, which is also recommended by Gupta and Uwilingiye (2008) for South Africa, we obtain an elasticity of money demand equal to 0.21 based on the Fischer and Seater (1993) long-horizon approach. Given this,

$$
G_{3}=0.00079 * 0.21 * 0.153 *(1 / 0.0594) \mathrm{GDP}=0.00043 \mathrm{GDP} \text { or } 0.043 \text { percent of GDP. }
$$

\section{The Revenue Effects of Reduced Money Demand}

The reduction in inflation affects government revenue in three ways. First, the reduction in the inflation tax on money balances results in a loss of Seignorage and therefore, an associated welfare loss of raising revenue by other distortionary taxes (Phelps, 1973). In equilibrium, inflation at rate $\pi$ implies revenue equal to $\pi M$. Increases in inflation raise the seignorage revenue by:

$$
\begin{aligned}
& d \text { Seignorage } / d \pi=M+\pi(d M / d \pi) \\
& =M / G D P\left\{1-\varepsilon_{M}\left[d\left(r_{n}+\pi\right) / d \pi\right]\left(\pi / r_{n}+\pi\right)\right\} G D P \\
& \mathrm{M}=0.153 \mathrm{GDP}, \varepsilon_{M}=0.21, d\left(r_{n}+\pi\right) / d \pi=0.765, \pi=0.02 \text { and } r_{n}+\pi=0.0594
\end{aligned}
$$

A decrease of inflation from $\pi=0.02$ to $\pi=0$ leads to a loss of seignorage by $0.0029 \mathrm{GDP}$.

The corresponding welfare loss is $0.29 \times \lambda$ percent of GDP. With $\lambda=0.4$, the welfare cost of lost seignorage is 0.116 percent of GDP. Clearly, the benefit of reducing inflation via an increase in money demand is outweighed by the loss of revenue from seigniorage. Specifically, a reduction of inflation by two percent would imply a welfare loss of 0.116 percent of GDP, which is obviously much less than the 0.098 percent gain that could be obtained using the estimation and calculations of Gupta and Uwilingiye (2008a).

The second revenue effect is the revenue loss that results from shifting capital to money balances from other productive assets. The decrease in business capital is equal to the increase in the money stock,

$$
M_{1}-M_{2}=\left[d M / d\left(r_{n}+\pi\right)\right](0.0153)=0.0153 \varepsilon_{M} M\left(r_{n}+\pi\right)^{-1}=0.83
$$

percent of GDP. When these assets are invested in business capital, they earn a real pretax return of 7.06 percent, but a net of tax return of only 4.41. The difference is the corporate and personal tax payments of 2.65 percent. Applying this to the increment in capital of 0.83 percent of GDP implies a revenue loss of $0.0265 \times 0.83=0.022$ percent of GDP. The welfare gain from this revenue loss is $0.022 \lambda$ percent of GDP. Again with $\lambda=0.4$, the welfare loss from this source is 0.009 percent of GDP.

The third revenue effect of the change in the demand for money is the result of the government's ability to substitute the increases in money balance of $M_{1}-M_{2}$ for interest bearing government debt. Although this is a onetime substitution, it reduces government debt service permanently by:

$$
r_{n g}(M 1-M 2)
$$

where $r_{n g}$ is the real interest rate paid by the government on its outstanding debt, net of the tax that it collects on those payments, given by $r_{n g}=0.75(0.153)-0.075=0.04$. 
The reduced debt service cost is $0.04\left(M_{1}-M_{2}\right)=0.00033$ or 0.033 percent of GDP. For $\lambda=0.4$, the corresponding welfare gain is equal to 0.013 percent of GDP.

Combining all three effects, we have total revenue losses equal to 0.112 when $\lambda=0.4$. The net welfare loss due to decreased revenue is equal to 0.07. Note Phelps' (1973) revenue effects are bigger than Bailey's (1956) money demand effect, which, in turn, means that the welfare loss from reduced seignorage revenue is bigger than the welfare gain from the reduced distortion of money demand following a move from two percent inflation to price stability.

\section{Debt Service and the Government Budget Constraint}

Finally, we analyze the effect of the higher real cost of servicing the national debt following a reduction in the inflation rate. With inflation, the nominal interest payments are taxed; therefore, lower inflation reduces the nominal interest rate on government debt and reduces the real value of taxes on interest payment to individuals. A lower inflation hence leaves real pre-tax interest rate unchanged which leads to no change on pre-tax cost of debt service, but reduces the tax revenue on the government debt payments which, in turn, leads to a higher level of other distortionary taxes.

Assuming a constant debt to GDP ratio, the increases in the real value of interest payments is equal the product of the change in inflation times the marginal tax rate on interest payment, $\theta_{i}$ (which we assume to equal to average marginal individual tax rate) times the ratio of debt, $B$, to GDP, as shown in Feldstein (1997). Hence, the welfare effect of the change in taxes required to offset the change in real government revenue is ${ }^{22}$ :

$d \mathrm{REV} V_{4}=-d \pi \times \theta_{i} \times B / G D P$

$=-0.02 \times 0.25 \times 0.41=0.00205$ or 0.21 percent of GDP.

The reduction of inflation by two percentage point will reduce the welfare by $0.21 \lambda$.

With $\lambda=0.4$, the net welfare revenue is -0.08 percent of GDP.

\section{The Net Effect of Lower Inflation on Economic Welfare}

We can now bring together the several effects of reduced inflation that have been identified and evaluated in the previous sections and compare them with the one-time output losses required to achieve the inflation reduction. As can be seen from Table 1, adding up all four distortions, we obtain a welfare gain of 0.225 percent of GDP welfare by moving from an average inflation of two percent to price stability. But when compared to Feldstein's (1997) estimate, our welfare gain is four times less than what he obtained. ${ }^{23}$ This is mainly due to the fact that the gain due to a move from two percent inflation to price stability, resulting from the distortions on intertemporal allocation of consumption and the housing market demand, is much higher in the case of the USA when compared to South Africa. This, in turn, results from the facts that the tax structure has a smaller distortionary effect on the choice between current and future consumption in emerging economies, like South Africa than in the US, and also because with interest payment and property rates not being tax deductable, inflation affects demand for housing only indirectly. However, at the same time, what is more important to us is that this measure of welfare loss is bigger than the value of 0.098 percent of GDP that could be obtained using the consumer surplus approach used by Gupta and Uwilingiye (2009b), which merely measures the distortion in the money demand due to positive nominal interest rates.

\footnotetext{
${ }^{22}$ See Feldstein (1997) for details on derivations to obtain equation (18).

${ }^{23}$ In fact, in general, barring Poland, estimated at 0.125 percent of GDP, our estimate of welfare gain is less than all the other estimates, obtained using Feldstein's (1997, 1999) approaches, available in the literature. Specifically, the welfare gains following a permanent reduction of inflation by 2 percent was found to be 1.41 percent of GDP in Germany, 0.39 percent of GDP in New Zealand, 1.88 percent of GDP in Spain and 0.316 percent of GDP in Ukraine. The only estimate that comes close to that of ours is that of the United Kingdom, which is measured at 0.21 percent of GDP.
} 
Table 1: Overall Welfare Gain of Moving from Two Percent Inflation to Price Stability

\begin{tabular}{|l|c|c|}
\hline \multirow{2}{*}{ Welfare effect } & \multicolumn{2}{|c|}{ Welfare gain as percent of GDP } \\
\cline { 2 - 3 } & South Africa & Feldstein (USA) \\
\hline Inter-temporal & 0.37 & 0.926 \\
\hline Housing Demand & 0.005 & 0.22 \\
\hline Money Market & -0.07 & -0.034 \\
\hline Debt servicing & -0.08 & -0.100 \\
\hline Total & 0.225 & 1.012 \\
\hline
\end{tabular}

Moreover, once we take into account Feldstein's $(1997,1999)$ argument that benefits of inflation are permanent, and hence, one should obtain its present value from reducing inflation permanently by two percent, even the relatively small-sized welfare gain of 0.225 percent of GDP translates into 15 percent of GDP, realizing that the relevant discount rate is $\left(r_{a}-\chi\right)$, since benefits grow at the same rate, $\chi$, as GDP. Recall that $r_{a}$ is the after-tax real return on savings and equals 3.94 percent, while the average growth rate of GDP $(\chi)$ for 1990-2007 was 2.44 percent, yielding a discount rate of 66.67. On the other hand, given that the sacrifice ratio for South Africa is $0.017^{24}$ percent of GDP (Tunali, 2008), the one-time cumulative loss of output is 0.034 percent of GDP following a reduction in the inflation rate from two percent to zero. Clearly, the current benefits, not to say the present value of the same, overwhelmingly outweigh the output loss originating from such a disinflationary policy.

\section{CONCLUSION}

This study makes the first attempt to calculate the benefit of moving from low inflation to price stability in South Africa using a micro partial equilibrium framework developed by Feldstein (1997, 1999). Looking at interaction between inflation and a non-indexed tax system, our calculations show that the benefits for moving from an inflation of two percent to zero is equal to 0.225 percent of GDP, which is more than twice the size of the estimates that could be obtained following Bailey's (1956) consumer surplus approach, based on the interest elasticity of money demand calculated by Gupta and Uwilingiye (2009b).

The paper emphasizes the distortions caused by the interaction of inflation and capital income taxation in calculating the gain from moving to a zero rate of inflation. Though the annual dead weight loss of a two percent inflation rate is a relatively small number when compared to the literature, since the real gain from shifting to price stability is permanent, the present value is a substantial multiple of the annual welfare gain and is found to be 15 percent of GDP. Since the corresponding one-off output cost of moving from two percent inflation to price stability is 0.034 percent of GDP, the gain outweighs the cost by an overwhelming margin. Further, when one realizes that the calculations are symmetric and, approximately, linear, our results make a strong case for rethinking the width and the upper and lower limits of the target band, at least from the point of view of welfare costs of inflation. Clearly, the discounted welfare gains will be quite substantial by moving to a narrower and lower target band and would also come at no cost to employment and output.

Dotsey and Ireland (1996) evaluated the welfare cost of inflation in dynamic general equilibrium endogenous and exogenous growth frameworks. By viewing inflation as a tax on micro-level decisions, the authors were able to identify explicitly, and quantify empirically, sizeable welfare costs of inflation at a macroeconomic level, indicating that a partial equilibrium approach, like the one used in this paper, can significantly underestimate the cost of inflation. Given this, there is no denying the fact that one can achieve possibly larger gains by reducing the inflation in a dynamic general equilibrium endogenous growth economic structure and that it is an important research question for the future to correctly evaluate the inflation targeting regime in South Africa based on welfare cost estimates.

\footnotetext{
${ }^{24}$ Gonçalves and Carvalho (2008) obtain negative numbers for the sacrifice ratio, implying that disinflation can be achieved without any output costs.
} 


\section{AUTHOR INFORMATION}

Josine Uwilingiye is currently a PhD candidate in the department of Economics at the University of Pretoria. Josine received her Bcom(Honours) Degree in Economics and Masters Degree in Econometrics from the University of Pretoria. Her research interests are in Macroeconomics and Monetary Economics. Up to now she has published 7 research articles in reputable local and international journals.

Rangan Gupta is currently a Professor at the Department of Economics, University of Pretoria. After having completed my Ph.D. in May 2005 from the Department of Economics, University of Connecticut, I joined the Department of Economics, University of Pretoria, as a Senior Lecturer in August 2005 and got promoted to an Associate Professor in July 2007. I secured my BSc (Honours) degree from the R.K.M.R. College, Narendrapur, and the MSc degree from the University of Calcutta. I have published over 60 journal articles in reputable domestic and international journals. My academic interests are mainly Monetary Theory and Policy.

\section{REFERENCES}

1. Akinboade, O. A.; F. K. Siebrits, and E. W. Roussot .2004. The Output Costs during Episodes of Disinflation in South Africa. Ninth Annual conference of Econometric Modelling for Africa.

2. Bailey, M. 1956. The welfare Cost of Inflationary Finance. Journal of Political Economy 64:93-110.

3. Bonato, L. 1998. Price stability: some costs and benefits in New Zealand. Reserve Bank of New Zealand Discussion Paper No G98/10 Reserve bank of New Zealand

4. Dolado, J.J; J.M. Gonzalez-Paramo, and J. Vinals. 1999. A cost-Benefit analysis of Going from Low to Price Stability in Spain. In M. Feldstein, ed., The costs and Benefits of Price stability Chicago, University of Chicago Press.

5. Dotsey, M.; P. Ireland. 1996. The welfare cost of inflation in General Equilibrium. Journal of Monetary Economics 37:29-47.

6. Feldstein, M. J. Green, and E. Sheshindki. .1978. Inflation and Taxes in a Growing Economy with Debt and Equity Finance. Journal of Political Economy 86(2), Part 2: Research in Taxation. pp. S53-S70.

7. Feldstein, M. 1997. The costs and benefits of going from low inflation to price stability... in C Romer and D. Romer ed., In reducing inflation: Motivation and Strategy,123 -156. Chicago: University of Chicago Press.

8. Feldstein, M .1999. Capital Income Taxes and the Benefit of Price Stability. In M. Feldstein, ed., The Cost and Benefit of Price stability, Chicago, University of Chicago Press.

9. Fisher, M.; J. Seater. 1993. Long-run neutrality and superneutrality in an ARIMA framework. American Economic Review 83:402-415.

10. Gonçalves, C. E. S.; A. Carvalho. 2008. Inflation Targeting and the Sacrifice Ratio. Revista Brasileira de Economia 62:177-188.

11. Gupta, R..; J. Uwilingiye. 2008. Measuring welfare cost of inflation in South Africa. South African Journal of Economics. 76:16-25.

12. Gupta, R.; J.Uwilingiye. 2009a. Measuring welfare cost of inflation in South Africa: A Reconsideration. South African Journal of Economic and Management Sciences 12:137-146.

13. Gupta, R.; J. Uwilingiye. 2009b. Time Aggregation, Long-Run Money Demand and Welfare Cost of Inflation, Studies in Economics and Econometrics 33:95-109.

14. Blaszkiewicz, M.; J. Konieczny; A. Myslinskaa; A. Radziwil, and P. Wozniak. 2003. Some benefits of reducing inflation in transition economies. Macroeconomies 0303004 EconWPA

15. Meltzer, A.H. 1963. The demand for money: the evidence from the Time series. Journal of Political Economy 71:219-246.

16. O'Reilly, B. and M. Levac. 2000. Inflation and the Tax System in Canada: An Exploratory Partial Equilibrium Analysis. Bank of Canada Working Paper 2000-18.

17. Phelps, E.S. 1973. Inflation theory of public finance. Swedish journal of Economics 75:67-82.

18. Tödter, K-H.; G. Ziebarth.1999. Price Stability versus Low Inflation in Germany: An Analysis of Costs and Benefits. In M. Feldstein, ed., The Cost and Benefit of Price stability Chicago, University of Chicago Press.

19. Tunali, D. 2008. Inflation Targeting and The sacrifice Ratio: The effect of Monetary Policy Design. Rutgers University.

20. Walsh, C.E. 2003. Monetary Theory and Policy, second Edition. Cambrige, Massachusetts, London, England: The MIT press,

21. Woglom, G.2005. Forecasting South African Inflation. South African Journal of Economics 75: 302-320. 